\title{
Motivation factors for schoolchildren of the indigenous small-numbered peoples of the North, Siberia, and the Far East of the Russian Federation to study native languages
}

\section{Fatores de motivação para crianças em idade escolar dos pequenos povos indígenas do Norte, Sibéria e Extremo Oriente da Federação Russa para estudar línguas nativas}

\section{Factores de motivación para que los escolares de los pueblos indígenas numerados del norte, Siberia y el Lejano Oriente de la Federación de Rusia estudien idiomas nativos}

\author{
Elena A. Naydenova ${ }^{1}$ iD \\ ${ }^{1}$ Federal Institute of the Native Languages of the Peoples of the Russian Federation, Yakutsk Branch, Yakutsk, Russia. \\ Corresponding author: \\ Elena A. Naydenova \\ Email: festival-etno@mail.ru \\ How to cite: Naydenova, E. A. (2021). Motivation factors for schoolchildren of the indigenous small-numbered peoples \\ of the North, Siberia, and the Far East of the Russian Federation to study native languages. Revista Tempos e Espaços \\ em Educação, 14(33), e16913. http://dx.doi.org/10.20952/revtee.v14i33.16913
}

\begin{abstract}
The extent to which a language is used affects its level of vitality. If a language is not included in a variety of spheres of human interaction, it joins the ranks of minority languages - the endangered languages (as opposed to the majoritarian languages, which are not threatened). In this regard, of serious concern is the state of the languages of the indigenous small-numbered peoples of the North, Siberia, and the Far East, the population of which does not exceed 50 thousand people. The number of speakers of these languages is decreasing rapidly every year. As part of the state assignment of the Ministry of Education of the Russian Federation on the topic "Development of a didactic system and methodology for creating a developing speech environment in a native language in the educational organizations located in the areas inhabited by the indigenous smallnumbered peoples of the North, Siberia, and the Far East of the Russian Federation", the author surveyed the representatives of three social groups from 12 rural settlements in six regions of the Russian Federation. The purpose of the survey was to determine the extent to which they use their native languages, the place of these languages in the ranking of languages they know, and their motivation for learning them.
\end{abstract}

Keywords: Indigenous minorities of the North, Siberia, and the Far East of the Russian Federation. Minority languages. Primordialism. Instrumentalism. 


\section{RESUMO}

A extensão em que uma língua é usada afeta seu nível de vitalidade. Se uma língua não está incluída em uma variedade de esferas da interação humana, ela se junta às fileiras das línguas minoritárias - as línguas ameaçadas (em oposição às línguas majoritárias, que não são ameaçadas). A esse respeito, preocupa seriamente o estado das línguas dos pequenos povos indígenas do Norte, da Sibéria e do Extremo Oriente, cuja população não ultrapassa 50 mil pessoas. $O$ número de falantes dessas línguas está diminuindo rapidamente a cada ano. Como parte da atribuição estatal do Ministério da Educação da Federação Russa sobre o tema "Desenvolvimento de um sistema didático e metodologia para a criação de um ambiente de fala em desenvolvimento em uma língua nativa nas organizações educacionais localizadas nas áreas habitadas por pequenos indígenas. povos numerados do Norte, Sibéria e Extremo Oriente da Federação Russa ", o autor entrevistou representantes de três grupos sociais de 12 assentamentos rurais em seis regiões da Federação Russa. O objetivo da pesquisa era determinar até que ponto eles usam suas línguas nativas, o lugar dessas línguas na classificação das línguas que conhecem e sua motivação para aprendê-las.

Palavras-chave: Minorias indígenas do Norte, Sibéria e Extremo Oriente da Federação Russa. Línguas minoritárias. Primordialismo. Instrumentalismo.

\section{RESUMEN}

La medida en que se usa un idioma afecta su nivel de vitalidad. Si una lengua no está incluida en una variedad de esferas de interacción humana, se une a las filas de las lenguas minoritarias: las lenguas en peligro de extinción (a diferencia de las lenguas mayoritarias, que no están amenazadas). En este sentido, es motivo de grave preocupación el estado de las lenguas de los pueblos indígenas reducidos del Norte, Siberia y el Lejano Oriente, cuya población no supera las 50 mil personas. El número de hablantes de estos idiomas disminuye rápidamente cada año. Como parte de la asignación estatal del Ministerio de Educación de la Federación de Rusia sobre el tema "Desarrollo de un sistema didáctico y metodología para la creación de un entorno de habla en desarrollo en una lengua nativa en las organizaciones educativas ubicadas en las áreas habitadas por los pequeños indígenas- pueblos enumerados del norte, Siberia y el Lejano Oriente de la Federación de Rusia ", el autor entrevistó a los representantes de tres grupos sociales de 12 asentamientos rurales en seis regiones de la Federación de Rusia. El propósito de la encuesta fue determinar en qué medida usan sus idiomas nativos, el lugar de estos idiomas en el ranking de idiomas que conocen y su motivación para aprenderlos.

Palabras clave: Minorías indígenas del norte, Siberia y el Lejano Oriente de la Federación de Rusia. Idiomas minoritarios. Primordialismo. Instrumentalismo.

\section{INTRODUCTION}

The balance between majority and minority languages is the subject of debate among scholars in many countries. Recently, the issue of native languages and linguistic rights in education has been one of the central issues in public discourse.

For language preservation, the "Foundation for the Preservation and Study of Native Languages of the Peoples of the Russian Federation" was created by presidential decree in 2018 (Martyniva, 2021, p. 341). In the same year, the "Law on Education" was amended in connection with the introduction of the subject areas "Native Language and Native Literature Reading" (grades 1-4) and "Native Language and Native Literature" (grades 5-9), including Russian as the native language. The choice of the native language to be studied as a school subject is voluntary and is made by parents or legal representatives before the child enters the first and fifth grades (Ministry of Education of the Russian Federation, 2020).

At present, the search for an optimal combination of the study of the Russian language with

the preservation of and support for the linguistic diversity of the peoples of Russia continues. It 
remains not fully clear what criteria should be used to identify the native language, how many languages a person can have, and how to motivate a child to study and use their native language. During the Soviet period, society was convinced that a person could only have one native language, same as ethnicity - the language of their ethnic group. In today's global world, it is believed that people have become more ethnically and linguistically complex, which makes it difficult to define one's native language.

\section{THE LANGUAGE SITUATION IN RUSSIA: STATE, OFFICIAL, AND NATIVE LANGUAGES. UNDERSTANDING OF THE “ETHNOS-LANGUAGE” CONNECTION IN DIFFERENT CONCEPTS}

The peculiar features of the language situation in Russia are:

- the presence of one all-national (federal) language - Russian, which is spoken by $99.4 \%$ of the population (2010 census), not only ethnic Russians, who make up about $80 \%$ of the population, and the knowledge of which is mandatory for all citizens;

- in accordance with the right granted by the Russian Constitution, around 40 languages of the most numerous non-Russian peoples are given the state status at the level of the Russian republics (Supreme Soviet of the RSFSR, 1991);

- at the level of autonomous okrugs, ethnic languages are recognized as official, for instance, the Nenets language in the Nenets Autonomous Okrug and the Khanty, Nenets, and Selkup languages in the Yamalo-Nenets Autonomous Okrug;

- at the level of individual republics, languages with the status of official exist in the absence of a state republican language (for instance, Karelian, Finnish, and Vepsian are official languages in the Republic of Karelia, but not state languages).

- at the level of individual republics, a state republican language is present alongside the languages with official status. For example, in the Republic of Sakha (Yakutia), the Yakut language has the status of the state republican language, and the languages of the small peoples of the North living on its territory have the status of official languages (the Dolgan, Evenk, Even, Yukaghir, and Chukchi languages).

As a consequence of this diversity, difficulties arise in understanding the difference between the state republican language and the official language. They are regarded as equal in a significant number of sources, yet in most cases, the official language is considered a narrower concept compared to the state republican language, namely:

- The state language of a constituent entity of the Russian Federation is the language spoken by the majority of the population and used in official records, court proceedings, and legislation on a par with the national (federal) language. All official signs and names (of institutions, streets, road signs) can be written in this language.

- The official language is the language permitted to be used by local governments of the country's constituent entities in places of concentrated residence of a national minority (Akademik, n.d.).

The interpretation of the fundamental category of a "native language" is ambiguous. Researchers define it based on at least the following four criteria:

- age of language(s) acquisition - languages learned by a person in early childhood;

- languages learned from parents (or people in loco parentis);

- languages that one speaks with maximum freedom and depth;

- ethnic identity, regardless of proficiency in the ethnicity's language (Zamiatin et al., 2012, p. 9).

The fourth criterion is directly contingent on the interpretation of the definitions of "ethnos" (ethnic group), "ethnic identity", and "ethnicity", as well as on the vision of the degree of connection between ethnicity and language. 
At the beginning of the 20th century, linguistics established the view that "the commonality of language creates ethnic unity"; thus, language and ethnicity are in inseparable unity. The same view is held by primordial ethnologists. In their opinion, an individual's awareness of their ethnicity lies in their genetic code, and, therefore, the language of an ethnic group is native to a person from birth (Sadokhin \& Grushevitskaia, 2000, pp. 92-98).

In the Soviet period, primordialism prevailed in all social sciences; in particular, its paradigm shaped the works of the linguist V.I. Abaev, ethnographers lu.V. Bromlei, G.lu. Markov, V. V. Pimenov, etc. The supporters of this school persist to this day (Tishkov, 2019, p. 133).

The opposite view is held by instrumentalists. The concept of "instrumentalism", which became widespread in Western ethnology in the mid-1970s, views ethnicity "as a tool used by political leaders to achieve their interests in the struggle for wealth, status, and power ... Ethnicity is a product of ethnic myths created by society's elite" (Tishkov, 2019, p. 137). The cultural characteristics, activities, and values of ethnic groups, including the strict attachment of language to ethnicity (without language there is no people), act as a tool of the elite used to mobilize the masses and embody their goals.

Language is a power that is utilized not so much through direct violence as through subjective prescriptions (indoctrination): family attitudes, the education system, the media, scientific bureaucratic classifications, language policy, including legal norms (Bourdieu, 2005; Myles, 2010; Swartz, 1998).

The constructivist theory is based on the notion that all intra-ethnic relations are based on the transmitted "cultural knowledge". It is only through this knowledge that one behaves appropriately in one's ethnic role and is seen as a member of an ethnic group. In any list of attributes of ethnicity, "perceptions of them" are introduced. Thus, for example, the signs of an ethnic community are not its common origin, but a representation or myth of a common historical destiny, culture, etc.

Thus, primordialists place ethnicity "in the heart of man," while instrumentalists (constructivists) place it "in his head" (Sikevich, 1999, p. 16).

Modern instrumentalists suggest less focus on the manifestations of "ethnicity" and consider language only as a sign system without tying it to ethnicity and ethnic culture.

The approach to language as an independent entity, and to its speakers not necessarily as an ethnic group, is now predominant, at least in the macroregion of Eurasia, with the exception of some countries of the former Soviet Union. It is no coincidence that the European Charter for Regional or Minority Languages is based precisely on the philosophy of the priority and intrinsic value of language itself, its status and prospects, not attaching this category of social reality to specific groups, much less to ethnonations and the 'ethnocultural development of the peoples of Russia. (Tishkov, 2019, p. 136).

The debate between the proponents of primordialism, instrumentalism, and constructivism is unlikely to end any time soon. Each of these three directions has its own weighty arguments, which should be considered. In our view, considering language only as a sign system is of interest to a narrow circle of professional linguists. Meanwhile, under certain conditions, associating language with the history and culture of an ethnos or ethnoses can be a good motivation to learn it for both the representatives of this ethnicity and people of other ethnicities.

In contemporary Russia, a considerable number of children are raised in ethnically mixed families and, in the current language situation, can learn two or even more languages from birth. For example, consider a child's mother is Even, the father is Yukaghir, and the family lives in a major city in the Republic of Sakha (Yakutia). Hypothetically, this child can learn as many as four languages from birth and consider them native: the Even and Yukaghir languages as the languages of the parents' ethnic groups, the Yakut and/or Russian language as the state languages, which are 
constantly used in the daily life of the multinational family and communication with the neighbors. At school, a foreign language, most commonly English, is also added to this list. The degree to which each of the languages will be used by the child in the future depends on many factors.

As applied to a separate individual, the choice of language and linguistic behavior are distinguished by the rational motives of the individual, although initially, of course, they are largely determined by the conditions of the family and community environment. Rationality and environment are inextricably linked, but their impact differs across different stages of life (Stefanenko, 1999; Tishkov, 2021, p. 20). Typically, the language that ends up being predominant is the one spoken by the majority of the population of the country (constituent entity) and has the official status, since knowing it makes it easier to travel across the country (constituent entity) and achieve success in life. "Competing with the language that feeds you, the language of 'craft and bread' that opens up access to social growth and a better, more prosperous life is difficult, if not impossible" (Filippova, 2013, p. 7). The other languages are pushed to the periphery. The rivalry between languages that affect identity is taking place not only domestically, but also globally. In particular, there is the global influence of English as the language of the political and business world, science and mass culture, information and communication. In this situation, the state language also needs to be protected (Tishkov, 2016, p. 295).

To determine the influence of ethnic identity on the identification of the native language (languages) and its place in the hierarchy of the surrounding languages in children from families of indigenous small-numbered peoples of the North, Siberia, and the Far East of the Russian Federation (ISPNS and FERF) (including mixed families), we conducted a survey of school students from 12 rural settlements in six regions of the Russian Federation with a concentrated population of the ISPNS and FERF. Third- and fourth-grade students and students in grades 5-9 participated in the survey.

\section{RELATIONSHIP “ETHNIC IDENTITY - ETHNIC GROUP LANGUAGE - NATIVE LANGUAGE" IN THE ASSESSMENTS OF STUDENTS IN SCHOOLS LOCATED IN THE AREAS OF CONCENTRATED RESIDENCE OF THE ISPNS and FERF}

Students are one of the three social groups surveyed as part of the study (2020-2021) (Naidenova, 2021).

In the course of the survey, all students indicated which ethnos/ethnoses they believe they are members of and specified the ethnicity (ethnicity) of their parents and their native language. In the interpretation of the survey data in tables and diagrams, the ethnicity of a child and their parents is signified with the first letter of the title of the ethnic group, for example, $Y$ - Yakut, E - Even, $R-$ Russian. For a child from a mixed family, the ethnicity of the parents is put through a fraction - the father's ethnicity at the top and the mother's at the bottom, for example, E/Y: Even father, Yakut mother. If a child identifies themselves or their parents as having two ethnicities (they or their parents come from a mixed family), the designations are written with a hyphen, e.g., R-E - RussianEven (Russian father, Even mother).

Here we will dwell in more detail on the results of the survey of schoolchildren from two villages in the Mom District of the Sakha Republic (Yakutia) - the villages of Khonuu and Sasyr, which are located at a considerable distance from each other and are compactly populated by the Evens.

The survey of the 3rd " $B$ " class of the Khonuu village primary school (Figure 1), where Russian is the language of instruction, the Yakut language is studied in class along with Russian, and Even language is studied as an elective (one hour per week by choice), shows that seven out of 15 students come from monoethnic Yakut families and eight are the children of mixed marriages. In specifying their ethnicity, the children from Yakut families self-identify as Yakut and name the Yakut as their mother tongue. Four children from mixed families identify with one of their parents' ethnicities, and four report having ethnically complex origin. When selecting the native language, the majority of the children from mixed families specify only one language. In particular, two people 
(1-Y-E/Y, $1-Y / E-Y)$ name the Even language as their native, three people indicate the Yakut language $(1-E / Y, 2-Y / E)$, two - Russian $(1-R / E, 1-R-Y / R)$, and one $(R / E-Y)$ - both the Yakut and Russian languages.

Figure 1. Ethnic composition - ethnic identity - native language in the identities of students in the 3rd "B" class, the village of Khonuu (language of instruction - Russian)

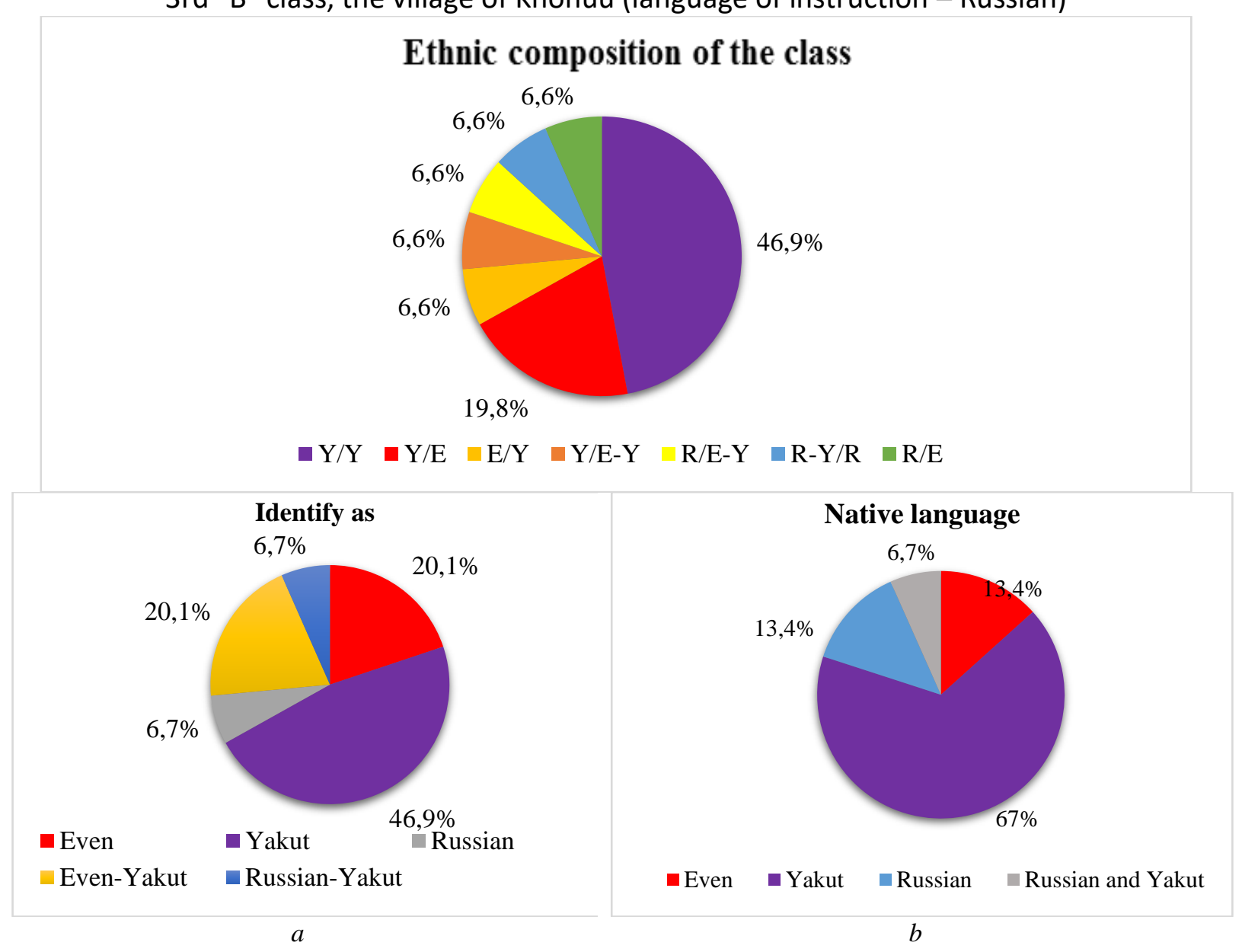

In the 3rd "B" class (Figure 2) of the same school, the language of instruction is Yakut. In addition, the Yakut language, along with Russian, is taught as a school subject.

Figure 2. Ethnic composition - ethnic identity - native language in the identities of students in the 3rd "B" class, the village of Khonuu (language of instruction - Yakut) 


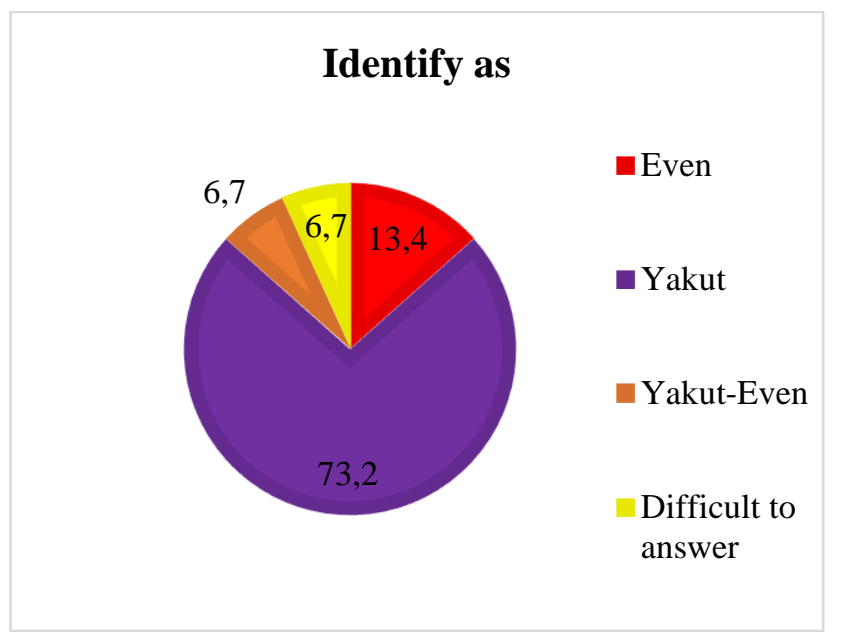

a

\section{Native language}

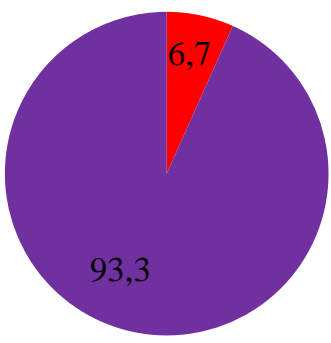

the Even language $\quad \square$ the Yakut language

Nine students from $\mathrm{Y} / \mathrm{Y}$ families identify as Yakut, one child does not specify their parents' ethnicities, five children identify as the members of mixed families, although four identify with the ethnicity of one of the parents (two consider themselves to be Yakut and two identify as Even) and one child identifies as Even-Yakut. Children from mixed families also give their preference to only one language when identifying their mother tongue. Commonly, it is the Yakut language, specifically, four of them consider Yakut as their native language, and one person selected Even.

A different situation is observed in the survey of $3 \mathrm{rd}$ and 4 th grades of the Sasyr village school (Figure 3), in which Even children constitute $76.5 \%$ of students and the language of instruction is Russian, while Even is taught in the classroom as the native language along with the Yakut language (parallel groups) in grades 1-11 (5 hours per week in grades 1-4; 3 hours per week in grades 5-9; 1 hour per week in grades 10-11) and in extracurricular activities.

Figure 3. Ethnic composition - ethnic identity - native language in the identities of students in the 3rd and 4th grades, the village of Sasyr (language of instruction - Russian)
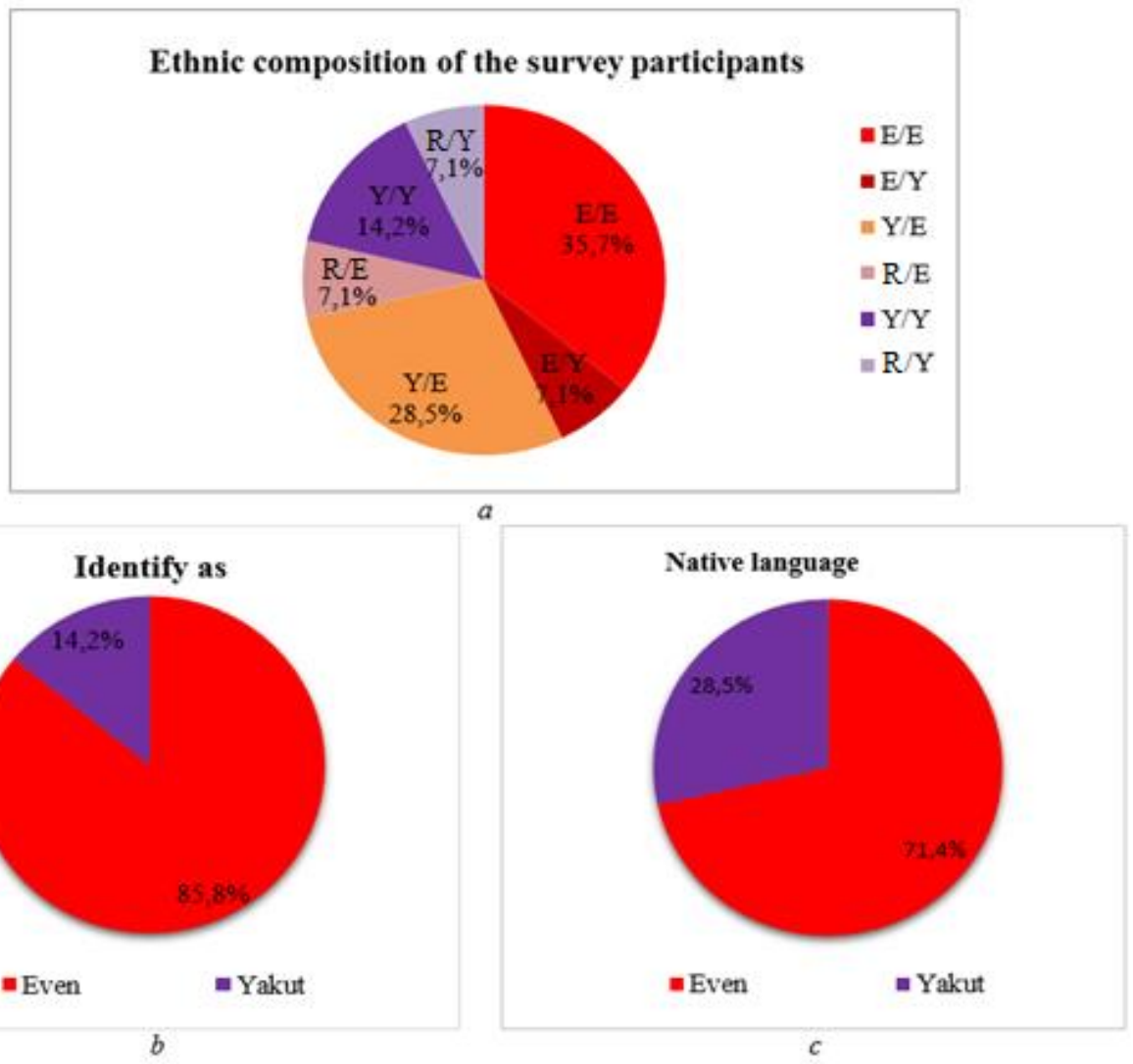
Out of the 14 surveyed students, 12 identify as Even, of which: five people (35.7\%) come from $E / E$ families, one person - from an $E / Y$ family, one student does not know the father's ethnicity and has an Even mother, one person is from a $Y / Y$ family, and four students come from $Y / E$ families; two people call themselves Yakut, of them: one person does not know the father's ethnicity and has a Yakut mother, one person is from a Y/Y family;

In identifying their native language: 10 students (71.4\%) select Even, of them: four people (28.5\%) from E/E families; three people (21.4\%) from $Y / E$ families, one person from a $Y / Y$ family; one person form an E/Y family; one person with an Even mother and unknown ethnicity of the father; four students (28.5\%) consider Yakut as their native language: one person form a $Y / Y$ family; one person from a $\mathrm{Y} / \mathrm{E}$ family; one person from a family with unknown ethnicity of the father and a Yakut mother; one person from an E/E family.

The survey of grade 7-8 students of the same school shows the following results (Figure 4).

Figure 4. Ethnic composition - ethnic identity - native language in the identities of students in the 7th and 8th grades, the village of Sasyr (language of instruction - Russian)

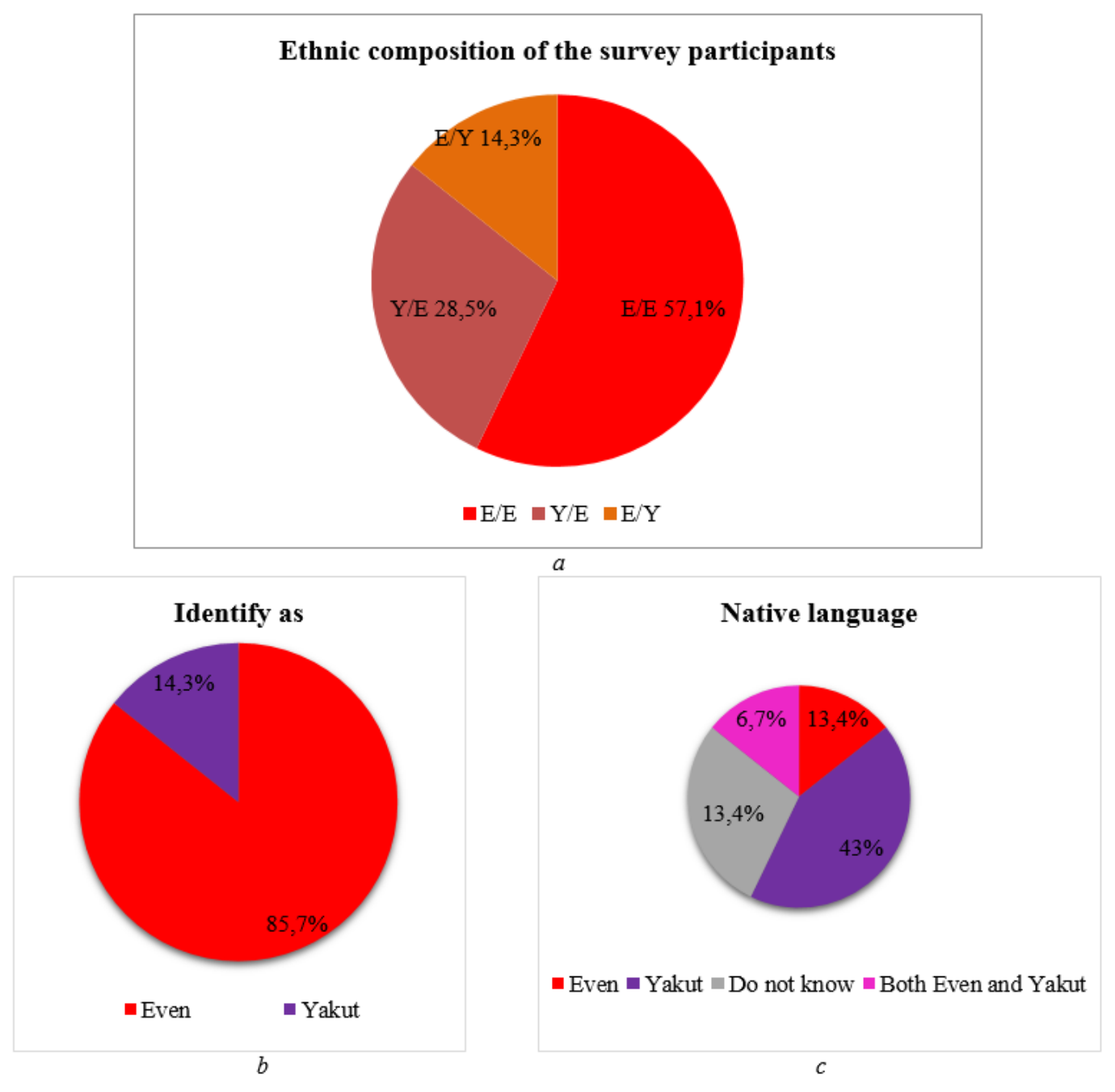

Out of seven respondents, six people identify as Even, of which: one person comes from an $E / Y$ family; one person from a Y/E family; four people from E/E/ families; only one student from a $\mathrm{Y} / \mathrm{E}$ family identifies as Yakut.

However, when identifying the native language, three students (two from E/E families and one from a Y/E family) name the Yakut language, one student from an E/E family indicates the Even language, two people (one from an E/Y family and one from a $Y / E$ family) have difficulty choosing 
the native language, and one person from an E/E family reports Russian and Yakut as their native languages.

The second block of the survey No. 3 questions focuses on children's self-reflection on their ability to understand the languages of the ISPNS and FERF, speak, read, and write in them, as well as their assessment of the representation of these languages in the space of the settlements. The ascertaining and self-analysis questions in this block are formulated as follows:

Are there languages that people in your village use that you do not know or do not know well? Name them.

In which language do you find the most inscriptions in your village, e.g., on buildings, signs? If there are several such languages, rank them - 1st to 3rd place, etc.

Is there a language that you know well, but there are no inscriptions in it in your village?

In what languages can you write and read?

Is there a language you can speak but cannot write?

The children of the Khonuu village report that there are no signboards in the Even language in their settlement; only one student notes the greeting in the Even language at the airport. In the Sasyr village, according to the survey data, signs in the Even language are present, including many inscriptions in the school itself. However, a significant number of respondents, including Even children, note that they have difficulties understanding the spoken language of their fellow Evenspeaking villagers.

The third block of the survey No. 3 concerns the status of the languages of the ISPNS and FERF in the students' linguistic repertoire. These questions can be called "polar" because they form pairs with opposite (polar) meanings. One half of the questions have an ascertaining nature ("using the language"/"not using the language"), while the other half is emotional-evaluative, i.e. implies the child's evaluation of each of the languages available in their attention zone ("attractiveness"/"unattractiveness"). The combined data allows deriving the rating of the languages of the ISPNS and FERF in the students' linguistic repertoire. The survey includes a total of six pairs of such questions:

Pair 1 . What language do you use with your teachers and classmates at school? (question 5) Is there a language you use at home that you do not speak (or hardly speak) with your teachers and classmates? Name it (question 6).

Pair 2. What language do you speak at home? If there are several such languages, put them in order, from the most to the least spoken (question 9). Is there a language that you know, but do not speak at home or do not speak much? Name it (question 10).

Pair 3. What language do you speak with your closest friends? If there are several such languages, put them in order, from the one you speak the most to the least often spoken (question 11). Is there a language you speak at home that you do not use with your closest friends? Name it (question 12).

Pair 4. Which language would you be especially interested in learning? If there are several such languages, rank them from the language you would like to learn first to the next most interesting language (question 13). Is there a language you are learning that you are not interested in learning? Name it (question 14).

Pair 5. What language or languages do you think you need to know to be successful? (question 15). Is there a language you are learning that you do not think you need to be successful in life? Name it (question 16).

Pair 6. Is there a language that you like very much because of its special qualities (sounds beautiful, etc.)? Name it and briefly explain why you like it (question 17). Is there a language that you do not like for some reason? Name it and briefly explain why you do not like it (question 18).

The answers to this block of questions served as a basis for compiling a summary sociometric matrix determining the degree of attractiveness of all the languages mentioned by the children. The 
primary school children in both villages typically did not hesitate to give an emotional assessment of the languages. In addition to Russian, Yakut, and Even, English and German were mentioned.

High school students tried to avoid negative emotional evaluations, but the range of languages mentioned increased (Chinese, Korean, etc.), with a personal interest in one or another language emphasized. Many noted the importance of learning the Even language and, at the same time, insufficient knowledge of it. A significant part of the respondents, including those not identifying as Evens, show interest in the Even language and express a desire to learn this language at least to understand their fellow villagers. The rating of the Even language among the schoolchildren is rather high.

A survey of general education students from five other regions (10 schools) that is based on the same principle provides similar results. Interestingly, in most of the studied schools, together with the representatives of the ISPNS and FERF, some children of other ethnicities learn these languages, choosing to study them voluntarily.

\section{CONCLUSION}

- The connection "ethnic identity - language of ethnicity - native language" is pronounced among 3rd-4th grade students from monoethnic families ( $Y / Y, E / E)$. Children from mixed families, in most cases, choose favor of the ethnicity of one of the parents; the identification of the native language is connected to it as well. In the situation of the predominantly Even environment (the Sasyr village school), a child from a mixed family more often identifies as Even, and in the school with the predominant Yakut population (Khonuu village), such students tend to identify as Yakut. Thus, in both cases, the priority is given to the majority group in the immediate environment. The ethnic self-identification of students in grades 7-8 follows approximately the same principle, yet their choice of the native language correlates with their ethnic identity to a lesser extent. The stereotypical notions existing in society that a native language must necessarily be associated with a person's ethnicity, and the discrepancy between these notions and the language used in domestic communication, in some cases, lead to the fact that children either have difficulty in defining the category of "native language" or, while being the representatives of the ISPNS and FERF families (in our case, Even families), name the Russian language as the state language and/or Yakut as their native language. In other words, some students reevaluate the connection between "ethnic identity - language of ethnicity - native language" in adolescence, while the choice of the native language can shift to the language used in daily life. Thus, one of the factors motivating students representing the ISPNS and FERF to learn these ethnic languages is the expansion of the spheres of their use in real life. Of no less importance for inspiring interest in the language is the awareness of the representatives of the ISPNS and FERF of them belonging to an ethnic group of status in society rather than to an outsider group. "Recognition of the right to native bilingualism relieves the tension and embarrassment many Russians feel when they have to choose between their father's and mother's native languages or simply between two languages that are equally native to them" (Tishkov, 2016, p. 302).

- The fact that some of the students who do not belong to the ISPNS and FERF, voluntarily

study the languages of these peoples indicates that the developing speech environment in the languages of the ISPNS and FERF created in schools has to be available to all willing to join it regardless of their ethnicity. The statements of school respondents of different ethnicities about their interest in learning the languages of the ISPNS and FERF to "understand their neighbors" (compactly living ethnic minority) sound reassuring. Popularization of the languages and cultures of the ISPNS and FERF among the population of constituent entities (the country as a whole) can raise their status and serve as a good motivation for their preservation and development.

- The presence of students whose ethnic group is represented in the school and community in an absolute minority, including children from the ISPNS and FERF (for example, 
Dolgans, Evenks, Yukaghirs, Nanai, and Nenets in the villages of Honuu and Sasyr), when they express a desire to learn the language of their ethnic group, suggests creating conditions for distance lessons with teachers from other regions where these languages are studied, as well as recording the results of these lessons in attestation documents.

Since the main factor of motivation to use any language in the modern world is its status, it is necessary to make the knowledge of minority languages, including the language of the ISPNS and FERF, prestigious in the entire Russian society and helpful for a person in their studies and career.

Authors' Contributions: Elena A. Naydenova: conception and design, acquisition of data, analysis and interpretation of data; analysis and interpretation of data, critical review of important intellectual content. Author have read and approved the final version of the manuscript.

Ethics Approval: Not applicable.

Acknowledgments: Not applicable.

\section{REFERENCES}

Akademik. (n.d.). Spisok gosudarstvennykh iazykov Rossii [List of the state languages of Russia]. Available: https://dic.academic.ru/dic.nsf/ruwiki/50405\#cite note-ReferenceB-2

Bourdieu, P. (2005). O proizvodstve i vosproizvodstve legitimnogo iazyka [The production and reproduction of legitimate language]. Otechestvennye zapiski, 2, 10-21.

Filippova, E. I. (2013). Predislovie. Sudba iazykov v globalizuiushchemsia mire [Preface. The fate of languages in a globalizing world]. In: Filippova, E. I. (Ed.). lazyki menshinstv: iuridicheskii status i povsednevnye praktiki. Rossiiskofrantsuzskii dialog [Minority languages: legal status and day-to-day practices. Russian-French dialogue]. Moscow: FSSI "Rosinformagrotekh", pp. 5-17.

Martyniva, M. lu. (2021). lazyk i identichnost skvoz prizmu rossiiskogo shkolnogo obrazovaniia [Language and identity through the prism of Russian school education]. In: Martynova, M. Iu. (Ed.). lazyk i identichnost: antropologicheskoe issledovanie situatsii v Rossii [Language and identity: An anthropological study of the situation in Russia]. Moscow: Institute of Ethnology and Anthropology of the Russian Academy of Sciences, 620 p.

Ministry of Education of the Russian Federation. (2020, November 3). Ministerstvo Prosveshcheniia podderzhivaet izuchenie iazykov narodov, zhivushchikh na territorii Rossii [The Ministry of Education supports the study of languages of the peoples living in Russia]. Available: https://edu.gov.ru/press/3089/ministerstvo-prosvescheniya-podderzhivaetizuchenie-yazykov-narodov-zhivuschih-na-territorii-rossii/

Myles, J. F. (2010). Bourdieu, language and the media. Basingstoke: Palgrave Macmillan.

Naidenova, E. A. (2021). Razvivaiushchaia rechevaia sreda na iazykakh korennykh malochislennykh narodov Severa metodologicheskie podkhody i praktiki [Developing speech environment in the languages of the indigenous peoples of the North: methodological approaches and practices]. Applied Linguistics Research Journal, 5(2), 227-237.

https://dx.doi.org/10.14744/alrj.2021.05668

Sadokhin, A. P., \& Grushevitskaia, T. G. (2000). Etnologiia: uchebnik dlia studentov vysshikh uchebnykh zavedenii [Ethnology: textbook for university students]. Moscow: Akademiia: Vysshaia shkola.

Sikevich, Z. V. (1999). Sotsiologiia i psikhologiia natsionalnykh otnoshenii. Uchebnoe posobie [Sociology and psychology of national relations. Textbook]. St. Petersburg: Mikhailov V.A. publishing house.

Stefanenko, T. G. (1999). Etnopsihologiia [Ethnopsychology]. Moscow: Institute of Psychology of the Russian Academy of Sciences; Akademicheskii proekt.

Supreme Soviet of the RSFSR. (1991). The Law of the Russian Federation of October 25, 1991 No. 1807-1 (as amended on June 11, 2021) "On the languages of the peoples of the Russian Federation". Bulletin of the Congress of the ND of the RSFSR and the Armed Forces of the RSFSR 12.12.91, No. 50, Items 1740, 1741, 1742.

Swartz, D. (1998). Culture \& power: The sociology of Pierre Bourdieu. Chicago: University of Chicago Press.

Tishkov, V. A. (2016). lazyki natsii [The languages of the nation]. Herald of the Russian Academy of Sciences, 86(4), 291-303. 
Tishkov, V. A. (2019). lazykovaia situatsiia i iazykovaia politika v Rossii (reviziia kategorii i praktik) [Language situation and language policy in Russia (Revision of categories and practices)]. Polis. Political studies, 3, 127-144. https://doi.org/10.17976/jpps/2019.03.08

Tishkov, V. A. (2021). Obnovlenie kategorii i praktik [The renewal of categories and practices]. In: Martynova, M. Iu. (Ed.). lazyk i identichnost: antropologicheskoe issledovanie situatsii v Rossii [Language and identity: An anthropological study of the situation in Russia]. Moscow: Institute of Ethnology and Anthropology of the Russian Academy of Sciences, $620 \mathrm{p}$.

Zamiatin, K., Pasanen, A., \& Saarikivi, J. (2012). Kak i zachem sokhraniat iazyki narodov Rossii? [Why and how to preserve the languages of the peoples of Russia?]. Helsinki: Vammalan Kirjapaino Oy.

Received: 8 August 2021 | Accepted: 14 November 2021 | Published: 21 December 2021 